\title{
Analysis of diversity among six populations of Colombian mango (Mangifera indica L. cvar. Hilacha) using RAPDs markers
}

\author{
Marcela Díaz-Matallana \\ Unidad de Biotecnología Vegetal \\ Departamento de Biología \\ Facultad de Ciencias \\ Pontificia Unidad Javeriana \\ Bogotá, D.C., Colombia \\ Ingrid Schuler-García \\ Departamento de Biología \\ Facultad de Ciencias \\ Pontificia Universidad Javeriana \\ Cra. 7 No. 43-82 Edificio Carlos Ortíz (52), $5^{\circ}$ piso. \\ Bogotá, D.C. , Colombia \\ E-mail: ischuler@javeriana.edu.co \\ Manuel Ruiz-García \\ Unidad de Genética y Biología del Desarrollo \\ Departamento de Biología \\ Facultad de Ciencias \\ Pontificia Universidad Javeriana \\ Bogotá, D.C., Colombia \\ Elizabeth Hodson de Jaramillo \\ Unidad de Biotecnología Vegetal \\ Departamento de Biología \\ Facultad de Ciencias \\ Pontificia Universidad Javeriana \\ Bogotá, D.C., Colombia
}

Financial Support: Research Programme "Young Researchers and Innovators" (2003-2005), funded by COLCIENCIAS (Instituto Colombiano Francisco José de Caldas para el Desarrollo de la Ciencia y Tecnología) and Pontificia Universidad Javeriana, Bogotá, D.C.

Keywords: genetic variability, mango Hilacha, organoleptic quality, RAPDs.

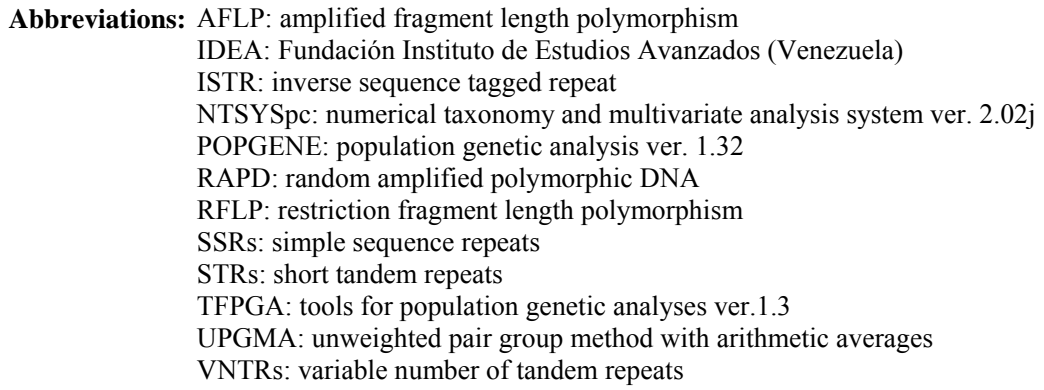

Currently in Colombia, there are only records of morph-agronomic characterizations of Mangifera indica cvar. Hilacha; molecular studies on this mango variety have not been carried out. The aim of this work was to identify the genetic diversity of six populations of mango Hilacha by RAPDs markers, as a fundamental base for breeding programs, conservation and selection of promissory materials for the fruit industry at the national level. From 60 primers evaluated in the populations, five primers were selected and were launched in the six populations. Polymorphic bands of RAPDs were transformed into binary matrices, which were then processed with NTSYS-pc, POPGENE and TFPGA softwares. The overall genetic diversity, $H_{T}=$ $0.468 \pm 0.0016$, is very similar to the average subpopulation genetic diversity, $\mathrm{H}_{\mathrm{S}}=\mathbf{0 . 4 4 3 1} \pm \mathbf{0 . 0 0 2 4}$, which revealed a small genetic differentiation among the mango Hilacha populations studied $\left(\mathrm{G}_{\mathrm{ST}}=\mathbf{0 . 0 5 3 2}\right)$.

*Corresponding author 
This means that each population contained in average $95 \%$ of the total genetic diversity found in the global population analyzed. Considerable gene flow between populations $(\mathrm{Nm}=9)$ was found. Finally, we recommend studying the genetic diversity of mango Hilacha populations with other molecular markers to complement the information obtained and to find similarities or differences with the results presented herein.

Colombia has cultivars of mango introduced from many foreign countries and its own native cultivars. The introduced cultivars were Haden, Kent, Keitt, Ruby, Tommy Atkins, Van Dyke, Palmer, Irwin and Zill. The Criollas or Colombian varieties are Albania, Mariquita, ICA-1834, ICA-1835, ICA-1837, Sufaida ICA-1, Piq 693, Bocado de Reina, Lorito, Chancleto, Mango de Azúcar, Mango Manzanita and Mango de Hilacha, the latter known with diverse names like: Magdalena River (fruit commercial name, for its production in the Magdalena River watershed), Hilaza(o), Criollo, Mango de Puerco and Mango Común (CCI, 1998; Bernal et al. 1999). Most mango Hilacha trees are not found solely in commercial plantations; instead, trees are dispersed throughout the entire Colombian territory.

Mango is used for human consumption mostly as fresh fruit (high contents of vitamins A, B, C, proteins and fiber), and as processed fruit (pulps, juices, sodas, etc). In immature state, it is suitable for elaborating flours for animal and human consumption (Rieger, 2006). The mango Hilacha possesses up to $21 \%$ of Brix grades (percentage of soluble solids), rendering it one of the most desirable fruits by the national industry of natural juices. The pulp of the mango Hilacha has been traded at the national level and exported mainly to the United States, Europe, Central America, the Caribbean, Canada and Japan (CCI, 1998; Vélez, 2000; Bavaria, 2007). Companies processing pulp export around 30,000 tons per year.

Currently, the crop has been characterized in Colombia mostly at the morphological level. Although morphological characteristics are very useful, they are affected by the

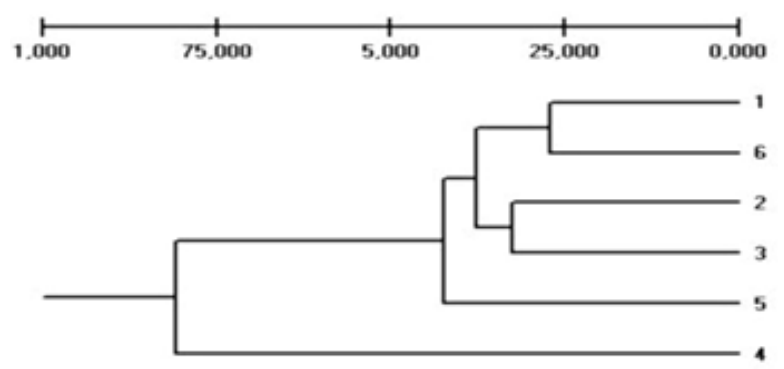

Figure 1. Dendrogram of Six populations of Mango Hilacha based on Nei (1972) and constructed by means of UPGMA algorithm. 1= Cundinamarca I, 2= Cundinamarca II, $3=$ Tolima I, $5=$ Valle, $4=$ Tolima II, 6= Cauca (TFPGA ver. 1.3). environment and they face heritability problems, while molecular markers are highly inheritable, are available at a high number and frequency, and exhibit enough polymorphism to discriminate against closely related genotypes (Stuber et al. 1999; Archak et al. 2003; Weising et al. 2005).

Different markers exist such as RFLPs, AFLPs, VNTRs, SSRs and RAPDs. The latter, in accordance with Williams et al. (1990), receive particular attention for several reasons: 1) previous information on DNA sequences is not required for designing specific primers; 2) the technique does not involve costly steps as those of Southern transfer, hybridizations, or use of radioactive isotopes; 3 ) it is quick, simple and automated and it requires small quantities of DNA (5-10 ng for each reaction) 4) The markers are dominant, that is two phenotypes are distinguished at each locus, with a band and with no band (Weising et al. 2005).

Several studies have been reported with different mango genotypes using RAPD (Schnell et al. 1995; LópezValenzuela et al. 1997; Kumar et al. 2001; Karihaloo et al. 2003), VNTRs, STRs (Schnell et al. 2005), ISTRs and AFLPs (Kashkush et al. 2001). Likewise, taxonomic studies have been carried out with the family Anacardiaceae and with Mangifera species based on pectin and phenolic compounds (Aguilar-Ortigoza et al. 2003; Berardini et al. 2005) and specific genomic sequences (Yonemori et al. 2002).

The aim of this research was to identify the genetic diversity among six populations of Mangifera indica var. Hilacha using RAPDs located in four departments of Colombia, as an essential requirement for plant breeding programs, conservation, and selection of promissory materials (Krishna and Singh, 2007) for the juice industry at the national level.

\section{MATERIALS AND METHODS}

\section{Plant material}

Plant material was obtained from individuals of Mangifera indica cvar. Hilacha coming from four departments of Colombia (Tolima, Cundinamarca, Valle del Cauca and Cauca) and selected by a team of technical assistants of the company Productora de Jugos S.A. The sample consisted of 112 individuals, as follows:

19 individuals from the high production zone I (950 - 1300 $\mathrm{m}$ in altitude) in Tolima, 19 individuals from the high production zone I $(950-1300 \mathrm{~m}$ in altitude) in Cundinamarca, 19 individuals from the low production zone II (300 - $1290 \mathrm{~m}$ in altitude) in Tolima, 19 individuals from the low production zone II (300 - $1290 \mathrm{~m}$ in altitude) in Cundinamarca, 18 individuals from the production zone (900 - $1400 \mathrm{~m}$ in altitude) in Valle del Cauca, 18 individuals from the production zone $(900-1400 \mathrm{~m}$ in altitude) in Cauca. 


\section{Selection of mango trees}

Mango trees were selected upon the following agronomic characteristics: well-formed tree-top with good symmetry, well-formed fruits, characteristics required in agro industrial processes, trees with low incidence of anthracnose and infestation of fruit flies, trees having a tradition of good production and trees adapted to the production areas, all of them more than 10 years old.

\section{DNA isolation}

Dry leaf tissue was macerated in liquid nitrogen, powdered PVP was added (40,000 MW) to counteract the phenols effect, and the powdered leaf tissue was stored at $-70^{\circ} \mathrm{C}$. Six (6) extraction protocols reported in the literature that had been assessed previously in the Plant Biotechnology Unit of the U. Javeriana were evaluated: 1) Dellaporta's method, modified version of Dellaporta et al. (1983); 2) Dellaporta's method, modified version of Dellaporta et al. (1983) with the addition of RNAse $(10 \mathrm{mg} / \mathrm{ml}) ; 3)$ method for coffee and cassava provided by IDEA; 4) QiaGen ${ }^{\circledR}$ DNAeasy Kit; 5) rice protocol, adjusted by González et al. (1995); and 6) Doyle and Doyle's, adapted by Schnell et al. (1995) and Doyle and Doyle (1990). Three individuals were selected from each department to find the protocol that best allowed obtaining DNA free of impurities and showing good quality for PCR amplification. The first protocol was chosen for the extraction of DNA. Extracted DNA was stored at $-20^{\circ} \mathrm{C}$. DNA quality was evaluated using 1) $1 \%$ agarose gel electrophoresis prepared in TBE $1 \mathrm{X}$, stained with ethidium bromide $0.5 \mu \mathrm{g} / \mathrm{ml}$, and 2) the purity relationship OD260/OD280 obtained by spectrophotometry. The extracted DNA was quantified $[\mu \mathrm{g} / \mathrm{ml}]$ using a spectrophotometer (BioSpec-1601 Shimadzu $\left.{ }^{\circledR}\right)$ with absorbance values of 260 and $280 \mathrm{~nm}$.

\section{DNA amplification conditions of PCR-RAPDs}

The genomic DNA was analyzed using RAPDs molecular markers (Williams et al. 1990; Schnell et al. 1995). We standardized the DNA amplification conditions by assessing the following: DNA concentration, primer concentration; different brands, concentrations and storage time of the Taq polymerase, as well as temperatures for PCR amplification $25 \mu$ l-reactions of PCR contained: $25 \mathrm{ng}$ of DNA, $0.25 \mathrm{mM}$ of dCTP, dGTP, dATP and dTTP respectively; $2.5 \mathrm{mM}$ of $\mathrm{MgCl}, 1 \mathrm{U}$ of Taq polymerase

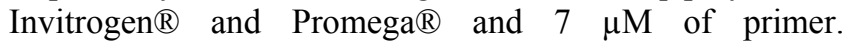
Thermocycler (Biorad MyCycler ${ }^{\circledR}$ ) was programmed for 34 cycles, with a denaturating step of $30 \mathrm{sec}, 94^{\circ} \mathrm{C}$, an annealing temperature of $40^{\circ} \mathrm{C}$ for $30 \mathrm{sec}$, and an extension step at $72^{\circ} \mathrm{C}$ for $1 \mathrm{~min}$.

Sixty Operon ${ }^{\circledR}$ RAPD's primers were evaluated: Kit A (120), Kit B (1-20), OPAA6, OPAB11, OPAB14, OPAC4, OPAC7, OPAC10, OPAD1, OPAD4, OPAD10, OPAD14, OPAG6, OPAG8, OPAH5, OPAH10, OPAM4, OPAM10, OPAM13, OPAN5, OPAN8 and OPAN17. Two individuals from each department were taken to select the primers that generated a good polymorphism level. A negative control and two positive controls were included (Curatella americana and a rice variety). From the 60 primers that were evaluated in the six populations, 10 did not amplify, 18 produced a low amplification, 11 primers were monomorphic, and 16 were polymorphic. Five (5) primers were selected from the 16 primers that were polymorphic (Table 1) and were therefore launched in the populations. The amplification products were run in $1.5 \%$ agarose gels prepared in TBE $1 \mathrm{X}$, stained with ethidium bromide [0.5 $\mu \mathrm{g} / \mathrm{ml}]$ and a voltage of $4-5 \mathrm{~V} / \mathrm{cm}$ was applied to the electrophoretic horizontal camera (Gibco ${ }^{\circledR}$ Horizon 20-25) for 2 hrs. Subsequently, the amplified products were visualized and photographed with the Gel Doc XR System (BioRad®).

\section{Data analysis}

The first statistic estimated was the expected heterozygosity (H) index. This statistic is important as a genetic variability measure because it is independent of the heterozygote individuals observed and therefore it is independent from positive or negative selection for homo and/or heterozygotes and from the reproductive strategies within a population. Differences among heterozygosity estimates were statistically analyzed with a Student $t$ test for sample pairs. The heterozygosity data were arcsine transformed prior to analysis, as proposed by Archie (1985).

A Nei's (1973) genetic diversity analysis was carried out to determine the genetic structure of the populations analyzed. The $\mathrm{G}_{\mathrm{ST}}$ statistic was used to measure the genetic differentiation between subpopulations relative to the genetic diversity in the total population.

An estimate of theoretical gene flow $(\mathrm{Nm})$ was obtained using the $\mathrm{G}_{\underline{\underline{T}}}$ statistic following an infinite island model (Ruiz-Garcia et al. 2006), where $\mathrm{Nm}=1 / 4\left(\left(1 / \mathrm{G}_{\mathrm{ST}}\right)-1\right)$.

Table 1. Operon ${ }^{\circledR}$ primers selected.

\begin{tabular}{|c|c|c|}
\hline No. & Primer & Sequence \\
\hline 1 & OPAB-14 & 5'-AAGTGCGACC-3' \\
\hline 2 & OPAC-4 & 5'-ACGGGACCTG-3' \\
\hline 3 & OPAC-7 & 5'-GTGGCCGATG-3' \\
\hline 4 & OPAG-6 & 5'-GGTGGCCAAG-3' \\
\hline 5 & OPAM-4 & 5'-GAGGGACCTC-3' \\
\hline
\end{tabular}


Table 2. Nei's genetic diversity analysis.

\begin{tabular}{|c|c|c|c|c|c|}
\hline Locus & Samble Size & $\mathrm{Ht}$ & Hs & Gst & Nm* \\
\hline OPAB14-1 & 110 & 0.4505 & 0.4492 & 0.0028 & 175.9351 \\
\hline OPAB14-2 & 110 & 0.4996 & 0.4805 & 0.0381 & 12.6156 \\
\hline OPAB14-3 & 110 & 0.4805 & 0.4569 & 0.0491 & 9.6868 \\
\hline OPAB14-4 & 110 & 0.4835 & 0.4120 & 0.1477 & 2.8842 \\
\hline OPAC4-1 & 108 & 0.4545 & 0.4386 & 0.0351 & 13.7638 \\
\hline OPAC4-2 & 108 & 0.4941 & 0.4822 & 0.0242 & 20.1929 \\
\hline OPAC4-3 & 108 & 0.4694 & 0.4600 & 0.0201 & 24.3830 \\
\hline OPAC4-4 & 108 & 0.4999 & 0.4903 & 0.0192 & 25.5496 \\
\hline OPAC7-1 & 109 & 0.3929 & 0.3564 & 0.0928 & 4.8851 \\
\hline OPAC7-2 & 109 & 0.4563 & 0.4499 & 0.0138 & 35.6785 \\
\hline OPAC7-3 & 109 & 0.3348 & 0.2849 & 0.1492 & 2.8518 \\
\hline OPAC7-4 & 109 & 0.4932 & 0.4629 & 0.0614 & 7.6395 \\
\hline OPAC7-5 & 109 & 0.4739 & 0.4329 & 0.0867 & 5.2669 \\
\hline OPAG6-1 & 109 & 0.4746 & 0.4601 & 0.0307 & 15.7944 \\
\hline OPAG6-2 & 109 & 0.4650 & 0.4011 & 0.1374 & 3.1401 \\
\hline OPAM4-1 & 112 & 0.4880 & 0.4514 & 0.0751 & 6.1600 \\
\hline OPAM4-2 & 112 & 0.4844 & 0.4665 & 0.0369 & 13.0578 \\
\hline OPAM4-3 & 112 & 0.5000 & 0.4877 & 0.0245 & 19.9214 \\
\hline OPAM4-4 & 112 & 0.4669 & 0.4552 & 0.0250 & 19.4699 \\
\hline OPAM4-5 & 112 & 0.4985 & 0.4834 & 0.0301 & 16.0987 \\
\hline Mean & 110 & 0.4680 & 0.4431 & 0.0532 & 8.8935 \\
\hline St. Dev & & 0.0016 & 0.0024 & & \\
\hline
\end{tabular}

${ }^{*} \mathrm{Nm}$ = estimate of gene flow from $\mathrm{G}_{\mathrm{st}}$ (POPGENE ver. 1.32).

Another measure applied to determine genetic heterogeneity among the populations was the Wright's $\mathrm{F}_{\mathrm{ST}}$ statistic using the Weir and Cockerham (1984) procedure and the Weir $(1990)$ nomenclature $\left(F_{\mathrm{ST}}=\theta\right)$. Jackknife over loci was applied to obtain a variance estimate of $\theta$ and bootstrap over loci was applied to generate $95 \%$ confidence intervals. 1,000 replications were done to carry out these Jackknife and bootstraps.

Exact tests with 1,000 demorizations, 10 batches and 2,000 permutations per batch were applied for all the samples taken together and among population pairs to determine the probability of significant heterogeneities.

The Nei's (1978) genetic distance was used to obtain genetic relationships among population pairs. The UPGMA and the neighbor-joining algorithms were applied to this genetic matrix to obtain phenograms where the global genetic relationships among the populations could be observed. All the analyses described were carried out with the TFPGA ver. 1.3, POPGENE ver. 1.32 and NTSYSpc ver. $2.02 \mathrm{j}$ softwares.

\section{RESULTS AND DISCUSSION}

\section{DNA isolation}

The evaluation of six extraction protocols showed that the modified protocol of Dellaporta et al. (1983), allowed obtaining a good quality DNA, which was confirmed by the electrophoresis with agarose gels where good quantity of DNA and no degradation were observed. It is necessary to 
point out that the DNA extracted using the Doyle and Doyle's modified protocol and the Qiagen ${ }^{\circledR}$ Kit, also presented good concentrations and was observed free of impurities in the agarose gel.

\section{Selection of operon ${ }^{\circledR}$ primers}

Out of the 60 primers that were evaluated in the six populations, 16 primers were polymorphic and five (5) primers were finally chosen (Table 1) because of their reproducibility. The same patterns of bands were evident when contrasting the banding patterns obtained in the selection gels vs. the banding patterns generated by the primers applied to the study collections. 20 polymorphic bands were produced with the five primers.

In general, reproducibility problems have been reported with RAPDs (Yu et al. 2002; Weising et al. 2005) and this was observed in our laboratory. For this reason, two amplification reactions were run separately with each primer and only the reproducible bands were considered.

\section{Data analysis}

The levels of genetic diversity were high and extremely similar within each sample analyzed and no significant differences were detected among them when a Student $t$ test with transformed arcsine data was applied (maximum value in Cundinamarca II, unbiased heterozygosity, $\mathrm{h}=0.476$ and minimum value in Tolima II, $\mathrm{h}=0.392$ ). Globally, the average unbiased genetic diversity was high $(\mathrm{h}=0.4683 \pm$ 0.038). Therefore, none of the populations studied seemed to be affected by evident genetic drift, founder effects or bottleneck events and gene flow seems to be important

Table 3. Nei's unbiased measures of genetic identity and genetic distance (1978).

\begin{tabular}{|c|c|c|c|c|c|c|}
\hline Pop ID & $\mathbf{1}$ & $\mathbf{2}$ & $\mathbf{3}$ & $\mathbf{4}$ & $\mathbf{5}$ & $\mathbf{6}$ \\
\hline 1 & $\star \star \star \star$ & 0.9803 & 0.9841 & 0.9296 & 0.9662 & 0.9963 \\
\hline 2 & 0.0199 & $\star \star \star \star$ & 0.9926 & 0.9590 & 0.9794 & 0.9860 \\
\hline 3 & 0.0160 & 0.0075 & $\star \star \star *$ & 0.9402 & 0.9829 & 0.9938 \\
\hline 4 & 0.0730 & 0.0419 & 0.0616 & $\star \star \star \star$ & 0.9187 & 0.9430 \\
\hline 5 & 0.0343 & 0.0208 & 0.0172 & 0.0848 & $\star \star \star *$ & 0.9911 \\
\hline 6 & 0.0037 & 0.0141 & 0.0063 & 0.0587 & 0.0089 & $* \star \star *$ \\
\hline
\end{tabular}

Nei's genetic identity (above diagonal) and genetic distance (below diagonal). 1: Cundinamarca I, 2: Cundinamarca II, 3: Tolima I, 4: Tolima II, 5: Valle and 6: Cauca. (POPGENE ver 1.32). enough to homogenize all the populations with a similar level of genetic diversity.

This was verified by the application of the Nei's (1973) genetic diversity analysis (Table 2). The overall genetic diversity, $\mathrm{H}_{\mathrm{T}}=0.468 \pm 0.0016$, is very similar to the average subpopulation genetic diversity, $\mathrm{H}_{\mathrm{S}}=0.4431 \pm$ 0.0024 , which revealed a small genetic differentiation among the mango Hilacha populations studied $\left(\mathrm{G}_{\mathrm{ST}}=\right.$ 0.0532). This means that each population contained in average $95 \%$ of the total genetic diversity found in the global population analyzed. This agrees quite well with the gene flow estimate obtained following the infinite Wright's island model, $\mathrm{Nm}=8.89$. This amount is very considerable. Recall that Ruiz-Garcia et al. (2005) showed that if $\mathrm{Nm}>1$ (in an infinite island model) or $\mathrm{Nm}>4$ (in a stepping-stone model), the gene flow is sufficient to attenuate the genetic differentiation between populations balanced for migration and genetic drift. According to the infinite island model, if $1<\mathrm{Nm}<0.5$, genetic differentiation among populations could be small but important in a stepping-stone model. When $\mathrm{Nm}<0.5$, populations are largely unconnected under any gene flow model. In our case, Nm was near 9, which denoted a very high gene flow among the populations studied. Slatkin and Barton (1989) showed that the method employed herein is robust, regardless the geographical location of the populations, the absence of gene drift-gene flow equilibrium or, even under the presence of natural selection affecting some marker. High gene flow is correlated with elevated levels of genetic diversity in populations (Ruiz-Garcia et al. 2006). In the case of mango Hilacha, flying pollinators (mango is an allogamus, crosspollinated species) and, especially, human intervention by transferring specimens from one population to another (Nybom and Bartish, 2000; Kiambi et al. 2005; Ward et al. 2005) may explain the high levels of gene flow detected.

The application of a hierarchical population model to obtain the $\theta\left(=\mathrm{F}_{\mathrm{ST}}\right)$ statistic with the Weir and Cockerham's (1984) procedure showed a similar result. The overall value of $\theta=0.0354 \pm 0.0114$ obtained by jackknifing over loci and the $95 \%$ confidence interval, $0.06-0.015$, with 1,000 bootstrapping over loci replicates, produced values nearly identical to that obtained with the $\mathrm{G}_{\mathrm{ST}}$ statistic (Table 2). According to Wright (1978), $\mathrm{F}_{\underline{S T}}$ values ranging from 0 to 0.05 indicate little or very little genetic differentiation, from 0.05 to 0.15 indicate moderate differentiation, from 0.15 to 0.25 indicate considerable genetic differentiation, and above 0.25 indicate very large genetic heterogeneity. The results obtained were consistent with null or very little genetic differentiation among the mango Hilacha populations studied.

The application of exact tests for genetic heterogeneity among population pairs also yielded a limited number of significant cases for several bands but not globally in neither case. The significant cases were as follows: among Cundinamarca I and Tolima I, the $4^{\text {th }}$ band of OPAC-7 (p = 0.0417), among Cundinamarca I and Tolima II, the $1^{\text {st }} \mathrm{m}$ 
band of OPAM-4 ( $\mathrm{p}=0.0159)$, among Cundinamarca I and Valle, the $5^{\text {th }}$ band of OPAC-7 $(\mathrm{p}=0.0238)$, among Cundinamarca II and Tolima II, the $4^{\text {th }}$ band of OPAB-14 $(p=0.0482)$, among Tolima I and Tolima II, the $2^{\text {nd }}$ band of OPAG-6 $(\mathrm{p}=0.0481)$, among Tolima I and Valle, the $5^{\text {th }}$ band of OPAC-7 ( $p=0.0291)$, among Tolima II and Valle, the $4^{\text {th }}$ band of OPAB-14 $(\mathrm{p}=0.0463)$, the $5^{\text {th }}$ band of OPAC-7 $(\mathrm{p}=0.0075)$ and the $2^{\text {nd }}$ band of OPAG-6 $(\mathrm{p}=$ 0.0152 ) (this was the pair case with most significant band differences, but overall there were no significant differences between both populations, $(p=0.3277)$, and among Tolima II and Cauca, the $4^{\text {th }}$ band of OPAB14 (p = 0.0071).

The results of the unbiased Nei's (1978) genetic distance among population pairs are shown in Table 3 . The highest genetic distance pairs were between Tolima II and Valle (D $=0.0848)$, Cundinamarca I and Tolima II $(\mathrm{D}=0.0730)$ and Tolima I and Tolima II ( $\mathrm{D}=0.0616)$. Therefore it is evident that Tolima II is the most differentiated of all the samples studied. Hernández et al. (2008) analyzed estimates of genetic differentiation in the allopatric speciation processes in diverse insect species. The local populations of a determined species showed an average Nei's genetic identity of $\mathrm{I}=0.967 \pm 0.006$, which is noteworthy similar to that detected herein $(I=0.9695 \pm 0.0254)$. Among subspecies and incipient species, the mean Nei's genetic identities were $0.795 \pm 0.013$ and $0.798 \pm 0.026$, respectively. Therefore, our mango Hilacha populations clearly correspond to populations of a same evolutionary lineage. That is, they are samples of a unique real population.

The UPGMA phenogram with the Nei's distance showed Tolima II as the most differentiated population, meanwhile Cundinamarca I and Cauca, firstly, and Cundinamarca II and Tolima I, secondly, showed strong relationships among them (Figure 1).

\section{CONCLUDING REMARKS}

Characterization of diversity is a necessary requirement for the improvement, use and conservation of plant genetic resources (Archak et al. 2003; Mignouna et al. 2003; Mohammadi and Prasanna, 2003; Weising et al. 2005; Krishna and Singh, 2007). RAPDs markers were used in this study because they allow estimating genetic diversity among organisms with unknown previous genetic information (Williams, 1990); in fact, the present investigation is the first report on the structure of the genetic diversity in the mango cultivar Hilacha in Colombia.

The high gene flow value observed in this work is seriously affecting the genetic diversity among mango Hilacha populations. It is probably caused by both insect pollinators and human intervention by repeatedly transferring materials from one population to another. Moreover, the high genetic diversity within populations is explained by the breeding system since mango is an allogamous species (Kiambi et al. 2005; Ward et al. 2005). The little genetic heterogeneity, in general, can also be due to the fact that this study focused only in a mango variety and not in other mango varieties.

It is highly recommended to use other combinations of RAPDs and other molecular markers such as AFLPs (Kashkush et al. 2001) and SSRs (Duval et al. 2005; Schnell et al. 2005), with the purpose of finding similarities or differences and to supplement the information provided by this study.

Moreover, the inclusion of material from Antioquia where mango Hilacha is also present, must be considered in future studies. Finally, for any future breeding programs of mango Hilacha and its conservation in Colombia, it is worthy to note that all the mango trees sampled possess a field number record kept by Productora de Jugos S.A. and therefore the geographical location of the sampled individuals is also known.

\section{ACKNOWLEDGMENTS}

Authors wish to thank the technical assistants of Productora de Jugos S.A. for supplying the samples, agriculture, climatic data and the organoleptic analysis; Gerardo Gallego, Myriam Cristina Duque (Biotechnology Unit, CIAT), Silvia Restrepo (Universidad de los Andes, Bogotá) for their contributions to this work; and Sandra Constantino for corrections to the English manuscript.

\section{REFERENCES}

AGUILAR-ORTIGOZA, C.J.; SOSA, V. and AGUILARORTIGOZA, M. Toxic phenols in various anacardiaceae species. Economic Botany, 2003, vol. 57, no. 3, p. 354-364.

ARCHAK, S.; GAIKWARD, A.B.; GAUTAM, D.; RAO, E.V.V.B.; SWAMY, K.R.M. and KARIHALOO, J.L. Comparative assessment of DNA fingerprinting techniques (RAPD, ISSR and AFLP) for genetic analysis of cashew (Anacardium occidentale L.) accessions of India. Genome, June 2003, vol. 46, no. 3, p. 362-369.

ARCHIE, J.W. Statistical analysis of heterozygosity data: independent sample comparisons. Evolution, 1985, vol. 39, no. 3, p. 623-637.

BAVARIA. Descripción de Productos de Exportación de Bavaria. 2007. Colombia. Available from Internet: http://www.bavaria.com.co/espanol/preguntas/preguntas_m arcas.php\#2

BERARDINI, N.; FEZER, R.; CONRAD, J.; BEIFUSS, U.; CARLE, R. and SCHIEBER, A. Screening of mango (mangifera indica L.) cultivars for their contents of flavonol $O$ - and xanthone $C$-glycosides, anthocyanins, and pectin. Journal of Agricultural and Food Chemistry, 2005, vol. 53, no. 5, p. 1563-1570. 
BERNAL, J.A.; TAMAYO, A.; LONDOÑO A. and HINCAPIÉ, M. Frutales de Clima Cálido. Cartilla Divulgativa. CORPOICA, Centro de Investigación "La Selva", Regional 4, Rionegro, Antioquia; SENA, Colombia, 1999, $1 \mathrm{p}$.

Corporación Colombia Internacional (CCI) Mango, Boletín CCI: SIM. Perfil del Producto, no. 1. September 1998. Available from Internet: http://www.cci.org.co/cci/cci_x/Sim/Perfil\%20de\%20Produ ctos/perfilmango1.html\#1.

DELLAPORTA, S.; WOOD, J. and HICKS, J.B. A plant DNA minipreparation: version II. Plant Molecular Biology Reporter, 1983, vol. 1, no. 4, p. 19-21.

DOYLE, J.J. and DOYLE, J.L. Isolation of plant DNA from fresh tissue. Focus, 1990, vol. 12, p. 13-15.

DUVAL, M.F.; BUNEL, J.; SITBON, C. and RISTERUCCI, A.M. Development of microsatellite markers for mango (Mangifera indica L.). Molecular Ecology Notes, July 2005, vol. 5, no. 4, p. 824-826.

GONZÁlEZ, D.O.; PALACIOS, N.; GALLEGO, G. and TOHME, J. Protocolos para marcadores moleculares. Unidad de Investigación en Biotecnología, Centro Internacional de Agricultura Tropical (CIAT); Colombia, Octubre 1995, 82 p. Publicación CIAT No. 258. ISBN 9589439-54-3.

HERNÁNDEZ, C.; RUIZ-GARCIA, M.; MUNSTERMANN, L.E. and FERRO, C. Estructura genética y autocorrelación especial en y entre cinco especies de flebótomos de la serie townsendi (Género Lutzomyia, Grupo verrucarum) en Colombia. Revista de Biología Tropical. In press. 2008.

KARIHALOO, J.L.; DWIVEDI, Y.K.; ARCHAK, S. and BALDEV GAIKWAD, A. Analysis of indian mango cultivars using RAPD markers. The Journal of Horticultural Science and Biotechnology, May 2003, vol. 78 , no. 3, p. 285-289.

KASHKUSH, K.; JINGGUI, F.; TOMER, E.; HILLEL, J. and LAVI, U. Cultivar identification and genetic map of mango (Mangifera indica). Euphytica, October 2001, vol. 122, no. 1, p. 129-136.

KIAMBI, D.K.; NEWBURY, H.J.; FORD-LLOYD, B.V. and DAWSON, I. Contrasting genetic diversity among Oryza longistaminata (A. Chev et Roehr) populations from different geographic origins using AFLP. African Journal of Biotechnology, April 2005, vol. 4, no. 4, p. 308-317.

KRISHNA, H. and SINGH, S.K. Biotechnological advances in mango (Mangifera indica L.) and their future implication in crop improvement: a review. Biotechnology Advances. May-June 2007; vol. 25, no. 3, p. 223-243.
KUMAR, N.V.H.; NARAYANASWAMY, P.; THEERTHA PRASAD, D.; MUKUNDA, G.K. and SONDUR, S.N. Estimation of diversity of commercial mango (Mangifera indica L.) cultivars using RAPD markers. Journal of Horticultural Science and Biotechnology, September 2001, vol. 76, no. 5, p. 529-533.

LOPEZ-VALENZUELA, J.A.; MARTINEZ, O. and PAREDES-LOPEZ, O. Geographic differentiation and embryo type identification in Mangifera indica L. cultivars using RAPD markers. Hortscience, 1997, vol. 32, no. 6, p. 1105-1108.

MIGNOUNA, H.D.; ABANG, M.M. and FAGBEMI, S.A. A comparative assessment of molecular marker assays (AFLP, RAPD and SSR) for white yam (Dioscorea rotundata) germplasm characterization. Annals of Applied Biology, 2003, vol. 142, no. 3, p. 269-276.

MOHAMMADI, S.A. and PRASANNA B.M. Review and interpretation, analysis of genetic diversity in crop plants salient statistical tools and considerations. Crop Science, July-August 2003, vol. 43, no. 4, p. 1235-1248.

NEI, M. Genetic distance between populations. American Naturalist, May-June 1972, vol. 106, 283-292.

NEI, M. Analysis of genetic diversity in subdivided populations. Proceedings of the National Academy of Sciences of the United States of America, December 1973, vol. 70 , no. 12, p. 3321-3323.

NEI, M. Estimation of average heterozygosiy and genetic distance from a small number of individuals. Genetics, July 1978 , vol. 89 , no. $3,583-590$.

NYBOM, H. and BARTISH, I.V. Effects of life history traits and sampling strategies on genetic diversity estimates obtained with RAPD markers in plants. Perspectives in Plant Ecology, Evolution and Systematics, December 2000, vol. 3, no. 2, p. 93-114.

RIEGER, M. Introduction to fruit crops. Chapter 19, Mango (Mangifera indica). Haworth Press, Inc. 2006. 462 p. ISBN 156022259X.

RUIZ-GARCIA, M.; OROZCO, P.; CASTELLANOS, A. and ARIAS, L. Microsatellite analysis of the spectacled bear (Tremarctos ornatus) across its range distribution. Genes and Genetics Systems, 2005, vol. 80, no. 1, p. 57-69.

RUIZ-GARCIA, M.; PAYAN, C.E.; MURILLO, A. and ALVAREZ, D. DNA Microsatellite characterization of the Jaguar (Panthera onca) in Colombia. Genes and Genetics Systems, 2006, vol. 81, no. 2, p. 115-127.

SCHNELL, R.J.; RONNING, C.M. and KNIGHT, R.J. Identification of cultivars and validation of genetic relationships in mangifera indica 1. using RAPD markers. 
Theoretical and Applied Genetics, 1995, vol. 90, p. 269274.

SCHNELL, R.J.; OLANO, C.T.; QUINTANILLA, W.E. and MEEROW, A.W. Isolation and characterization of 15 microsatellite loci from mango (Mangifera indica L.) and cross-species amplification in closely related taxa. Molecular Ecology Notes, September 2005, vol. 5, no. 3, p. 625-627.

SLATKIN, M. and BARTON, N.H. A comparison of three indirect methods for estimating average levels of gene flow. Evolution, 1989, vol. 43, p. 1349-1368.

STUBER, C.W.; POLACCO, M. and SENIOR, M.L. Synergy of empirical breeding, marker-assisted selection, and genomics to increase crop yield potential. Crop Science, 1999, vol. 39, no. 6, p. 1571-1583.

VÉLEZ, M.A. Productos potenciales de la biodiversidad que han tenido alguna experiencia en procesos de exportación. Instituto Alexander von Humboldt, Bogotá, D.C., Colombia. Biosíntesis, Boletín Informativo, December 2000, no. 25, 4 p. ISSN 0123-7896.

WARD, M.; DICK, C.W.; GRIBEL, R.; LEMES, M.; CARON, H. and LOWE, A.J. To self, or not to self. A review of outcrossing and pollen-mediated gene flow in neotropical trees. Heredity, 2005, vol. 95, no. 4, p. 246-254.

WEIR, B.S. Genetic Data Analysis: Methods for Discrete Population Genetic Data. Sinauer Associates, Inc. Sunderland, Massachusetts. 1990. ISBN 0-87893-902-4. $543 \mathrm{pp}$.

WEIR, B.S. and COCKERHAM, C.C. Estimating Fstatistics for the analysis of population structure. Evolution, November 1984, vol. 38, no. 6, p. 1358-1370.

WEISING, K.; NYBOM, H.; WOLFF, K. and KAHL, G. DNA Fingerprinting in Plants. Principles, Methods and Applications. $2^{\text {nd }}$ Edition. Taylor \& Francis Group, 2005, 444 p. ISBN 0-8493-1488-7.

WILLIAMS， J.G.K.; KUBELIK, A.R.; LIVAK, K.J.; RAFALSKI, J.A. and TINGEY, S.V. DNA polymorphisms amplified by arbitrary primers are useful as genetic markers. Nucleic Acids Research, 1990, vol. 18, no. 22, p. 6531-6535.

WRIGHT, S. Evolution and the genetics of populations, variability within and among natural populations. University of Chicago Press, Chicago. vol. 4. 1978. 580 p. ISBN 0226910415

YONEMORI, K.; HONSHO, C.; KANSAKI, S.; EIADTHONG, W. and SUGIURA, A. Phylogenetics relationships of Mangifera species revealed by ITS sequences of nuclear ribosomal DNA and a possibility of their hybrid origin. Plant Systematics and Evolution, March 2002, vol. 231, p. 59-75.

YU, Z.; LI-QIONG, L.; HUAN, L.; JIE, B.; MANG-YE, Y.; CHEN, M.; YING-FAN, C.; XIAO-LIN, Q. and FANG, C. RAPD markers in diversity detection and variety identification of tibetan hulless barley. Plant Molecular Biology Reporter, December 2002, vol. 20, no. 4, p. 369377. 